\title{
French Travellers' Treatises on Oriental Diseases and Symptoms: Indo-French Medical History
}

\author{
Sakul Kundra* and Bhawna ${ }^{\dagger}$
}

French travellers and adventures of the $17^{\text {th }}$ and the $18^{\text {th }}$ centuries had shown immense interest to explore the medical knowledge of the Orient. This article systematically analyzes their observations and evaluation on different diseases, symptoms and effects on patients which helped the travellers and adventurers of the later times by providing medical precautions to be taken before sailing on a voyage to the Orient. This article, based on many translated and un-translated records written in the form of letters, memoirs and travelogues by the French, who visited India, focuses on the varied facets given by them on medical knowledge and history of the Orient. Undoubtedly, the Portuguese and the English travellers also provided interesting accounts on oriental diseases, symptoms and their therapies but those given by the French are yet to be explored in detail.

There is no dearth of expert doctors and physicians in India but large amount of information provided by French travellers' record especially related to anatomy and remedies, is yet to be explored and would help us understand the intricacies of the Indian medical system of yesteryears as documented by the French. We come to

\footnotetext{
* Assistant Professor, Department of History, Centre of Humanities and Education, Fiji National University, Fiji Islands, Email: jnulec@gmail.com.

† French Research Scholar, Senior French and Business Management Teacher, Asst. MYP Coordinator, International School Nadi, Nadi, Fiji Islands.
} 
know that there was inadequacy of proper hospitals and medical instruments. Although many quacks practiced in India, there was a great demand for European doctors who seemed to have great medical expertise. At the same time, these travellers praised some Indian remedies and gave them the credibility they deserved. They also had the wisdom to identify the climatic differences between Occident and Orient that caused different diseases and offered respective remedies. This paper begins with brief biographical sketches of such significant French travellers, as Charles Dellon, Francois Bernier, Jean Baptiste Tavernier, Jean Mocquet and others who came to India between the years 1640-1685 and wrote in significant detail about the medical history of the Oriental world, with their objectives of explorations, time of voyage and medical expertise.

Charles Dellon ${ }^{1}$, in his memoir Traité des maladies particulières aux pays orientaux et dans la route et de leurs remèdes ${ }^{2}$ published in Paris in

${ }^{1}$ Charles Dellon was a member of the protestant church, who left France for the Indies on 20 th March, 1668. After his stay for one year in Madagascar he went to Surat, travelled to the Malabar Coast and gave a quite flattering description of India. He worked as a physician in Daman, where he was arrested by the Inquisition in 1673 for atheism. He was accused of three crimes, firstly for supporting the invalidity of Baptism, secondly, for denouncing the worship of the images and lastly, for criticizing the Inquisition and the judges of the tribunal. He was punished to five years of hard labour and sent to Goa, from where he was expelled to Portugal in 1676. Dellon's case was reviewed again in Lisbon, where at last he was released after the intervention of Bossuet. He returned to France in 1677, and became a physician to the Prince of Conti. Later, he married a girl of a rich butcher and settled in Paris. He died in 1710.

2 Dellon, Charles. Traite des Maladies aux Pays Orientaux, et Dans la Route et de leurs Remedes, Paris : MCDDEM 1685. Later this book was translated A Treatise of the Distempers Relating in the Particular to the Eastern Coutnries and Such other Diseases as commonly happen in the Voyages into those Parts, with their proper Remedies by M.C.D.D.E.M, trans. from French, London, Printed for D.Browne, at the black Swan without Temple Bar, 1698. The translations of this book is sometimes unclear. 
1685, devoted a large section, on particular diseases of the Orient ${ }^{3}$ and their remedies. ${ }^{4}$ He made his journey to India between 16681676, discussed about many diseases which were frequent in India such as vomiting, marine scurvy, mordechi, flux de ventre or dysentery, petite verole, small pox, grass snake bite and bicho or filariasis and bleeding.

Francois Bernier was known as a philosopher, astronomer and a physician who cleared the examination of the licentiate in medicine from the University of Montepellier in 1652. Bernier received scientific knowledge from his teacher named Pierre Gassendi. During his stay in India during 1658-1668, he visited Delhi, Agra, Lahore, Kashmir, Rajmahal, Kasimbazar, Beneras, Masulipatam and Golconda. ${ }^{5}$ As a physician, he evaluated the medical knowledge of India and worked successfully under the Mughals. ${ }^{6}$

Jean-Baptiste Tavernier, a French diamond merchant and a traveller, made six voyages to the East from 1631 to 1668 and finally retired to France wealthy and honoured. During his journey to India he visited Dacca (Dhaka, presently in Bangladesh), Agra, Surat, Burhampur, Ahmednagar, Goa and Golconda. He presents enormous amount of information on the commercial aspects to compatriots besides throwing light on some facets of medical knowledge.

Jean Mocquet had been apothecary to the court of French King Henry IV. He left France in 1601 and came to India to collect specimens to be kept in the royal cabinet of curiosities. He made five voyages; the fourth one took him to Goa on a Portuguese

${ }^{3}$ Charles Dellon said that he had a passion to travel from his childhood and after completing his studies, left Paris without any determined intention to seek future in foreign trade or knowledge of their manners.

${ }^{4}$ Dellon, Charles. Nouvelle Relation d'un Voyage fait aux Indes Orientales, Amsterdam: Paul Masset, 1699, p. 236-320.

${ }^{5}$ Bernier's goal was to explore India, to explore its hinterland and to visit the court of the Great Mughal. He also wanted to accumulate knowledge and had the desire to see the world.

6 Kundra, S. "Francois Bernier's discourse on the health system in medieval India" in National Medical Journal of India, July vol. 23, 2010. 
vessel, where he served for sometime as an apothecary in the Royal Hospital. ${ }^{7}$

Francois Martin de Vitre, French sailor and adventurer, travelled to East Asia as far as Sumatra from 1601 to 1603 . He was the first Frenchman to write an account of travels to the Far East. He not only wrote about the physical features of the people, clothes worn by high and low class people both men and women, food and currency, but also made observations about some animals, merchandise, aromatic drugs and fruits which were found in India. ${ }^{8}$ He stayed in India for a span of five months before reembarking towards France in $1602 .{ }^{9}$

Francois Pyrard, the French navigator cum traveller, stayed in India for during the period 1608-1611. After a brief stay in Bengal, he visited various ports on the Malabar Coast and spent nearly eight months at Calicut. This helped him to observe and admire this flourishing commercial city. When he failed to obtain passage on a ship headed to France, due to Portuguese diplomacy, Pyrard attempted to reach Cochin in March 1608 but was captured and made prisoner by the Portuguese. He was released after ten days and was transferred to Goa. At the Portuguese capital in India, he maintained it as his chief residence from May 1608 to February 1610. He also wrote about growing encroachments of the Dutch. Finally, on 30 February 1610, he left Goa for Europe but reached his

${ }^{7}$ Mocquet, Jean. Voyages en Afrique, Asie, Indes Orientales \& Occidentales: Divisez En Six Livres, \& enrichiz de Figures, Rouen, Jacques Caillove, 1645, p. 221. Mocquet left France in 1601, made five voyages in next eleven years: the first was to the western coast of Africa (returned to Saint-Malo on 1st August, 1602), the second to Cape Verde, Brazil, Guyana and Cumana, the third to Portugal and Morocco (departured from Saint-Nazaire on April 12th, 1605, returned to Havre on March 17th, 1606), the fourth to Ethiopia, Mozambique and Goa and parts of Africa and East Indies, the fifth to Syria, Jerusalem and Palestine.

8 Vitré, François Martin de. Description du premier voyage faict aux Indes Orientales par les Français, Paris: Laurens Sonnius, 1609, 2009. p. 111.

${ }^{9}$ Ibid., p. 90. 
native town of Laval in February 1611. By then He had stayed for ten years in the Maldive Islands and India (from 1601 until 1611). ${ }^{10}$

Jean de Thevenot was in the Mughal Empire of India in 1666, for thirteen months. He toured central India, Ahmadabad, Cambay and the Coromandel Coast. Across the Deccan peninsula, he proceeded towards Masulipatnam on the Eastern coast passing through Burhanpur, Aurangabad and Golconda and visited the rock cut temples of Ellora. ${ }^{11}$ Later, he took a ship to return to Europe via Persia ${ }^{12}$. He made valuable observations on the Indian medical system. Several other travellers such as Abbe Carre, Francois Pierre-Olivier Malherbe, Augustin De Bourdeaux, François De Gouz De La Boullaye, John Chardin and others have also made passing references but, yet, invaluable narratives regarding medical diseases existing in India.

\subsection{Dysentery}

Dellon mentions in his work that when a priest named Father Gabriel was attacked by a perilous dysentery, being of opinion that the Indian doctors might be better skilled to deal with this Indian disease, sent for a Pandit, who notwithstanding the violence of the symptoms, which to him were no good presages, promised to cure him in three days and prescribed him certain medicine which was being composed, as Dellon judged, of opium, that the Indians called Amphion, oil and jagre (jaggery), or sucre de coco to be taken a spoonful every night and morning. ${ }^{13}$ Tavernier mentions in India,

10 Pyrard de Laval, Francois. The Voyage of François Pyrard of Laval to the East Indies, the Maldives, the Moluccas, and Brazil, (Trans. \& Ed.) Albert Gray and H.C.P. Bell, London: Hakluyt Society, 1888, Vol. II, part. I, pp. x, ${ }_{11}$ Thevenot, Jean de. Voyage de Mr. De Thevenot, III Part ed. Surendranath Sen, Travels of Thevenot and Careri, Delhi: National Archives of India, 1949, pp. XVII, 1, 8, 11, 17.

12 Boissel, Jean. "Le voyage en Perse de Jean Thevenot", Cashiers de l'Association internationale des études francaises, 1975, No. 27, pp. 109-122.

${ }^{13}$ Dellon, Charles. Nouvelle Relation d'un Voyage fait aux Indes Orientales, Amsterdam : Paul Masset, 1699, p. 159. 
eating meat of buffaloes often causes dysentery, whereas beef was safe. ${ }^{14}$

Charles Dellon wrote about the ailment of flux de ventre or dysentery. He said Flux de ventre, of all other kinds of diseases, was contagious, difficult to cure, dangerous and often fatal, not only in Indies but also en route. Compared to Indians, the Europeans were more prone to get infected by it. They are cured with difficulty because of their intake of excess of wine and brandy, which are not in use among the majority of the Orients. If dysentery was accompanied by fever, which usually was the case, the Pandits prescribed Cangé and boiled rice without salt, with equal quantity of curdled and bitter milk which they claimed to be the only remedy for this disease. However according to the writer, it only had disastrous effects; the patients continued to suffer. The Pundits did not even make any use of harmless enema, which they feared would increase the disease. They only used remedies purely astringent to check the severity of the disease for the time being, without curing the root cause. Finally when the patients could not sleep due to severe pain they were administered several intakes of opium, without any proper preparation which sometimes amounted to as much as ten grains per each dose. ${ }^{15}$

Bernier also suffered from dysentery in Lahore. He writes, 'I was seized with a flux, accompanied by acute pains in my limbs, in consequence of having passed whole night on a terrace in the open air, as is commonly done in Delhi without danger. My health was suffering; but since we have been on a march, the violent perspirations, which continued for eight or nine days, have dissipated my bad humours, and my parched and withered body became a mere sieve, the quart of water, which I swallow at a draught passing at the same moment through every one of my pores, even to my fingers ends. I am sure that to-day I have drunk more than ten pints. Amid all our sufferings, it is a great consolation to be able to drink as much water as we please with

14 Tavernier, Jean Baptiste. Travels in India, 1640-67, (Trans.) V Ball, iii vols., New Delhi: Oriental Books, 1889; 1977, Vol 2, Book II, p. 30.

15 Dellon, Charles. Traite des Maladies aux Pays Orientaux, et Dans la Route et de leurs Remedes, Paris : MCDDEM 1685, p. 37. 
impunity, provided it be of a good quality'.16 This explanation of Bernier of the appropriate treatment of dysentery, must have helped both the Indians and the contemporary travellers regarding the cure of the disease.

Thevenot also has written on this deadly disease, whether plain or accompanied with blood, and said that its remedy was consumption of the powder of two Drachms of horrible Rhubarb and a Drachm of Cummin-seed mixed with lemon or rose-water. The common people of the Indies had no other remedy except consuming boiled rice along with sour milk only till the fever lasted. ${ }^{17}$

Anquetil Duperron, the French Indologist, fell ill due to fever and dysentery for three months. When he discharged some worms, the dysentery ceased. Then he took a spoonful of soup which helped him recover. ${ }^{18} \mathrm{He}$ again felt the symptoms of dysentery due to change of food when he reached Surat, so he found himself the solution of taking restricted diet and by taking several doses of ipecacuanha and cured himself in one and a half month. ${ }^{19}$

\subsection{Scurvy}

Charles Dellon gives a descriptive account of the disease called scurvy. He said 'French mariners called the scurvy as a land evil, which was the most dangerous and troublesome for voyagers being not only contagious, but also scarce ever to be cured till one gets ashore' $^{\prime 20}$

16 Bernier, Francois. Travels in the Mogul Empire AD 1656-1658 (Trans.) Irving Brock and (ed.) Archibald Constable, Delhi: Low Price Publications, 1934; 1994, p. 388.

17 Thevenot, Jean de. Travels of Thevenot and Careri, Sen, S.N. (ed.), The Indian Travels of Thevenot and Careri, New Delhi: National Archives of India, 1949. p. 152.

18 Duperron, Abrahma-Hyacinthe Anquetil. Extracts from the Narrative of Mons. Anquetil du Perron's Travels in India. (Trans.) By Kavasji Edalji Kanga, Bombay : Commercial Press, 1876, p. 10

${ }^{19}$ Ibid., p. 29

${ }^{20}$ Dellon, Charles. Traite des Maladies aux Pays Orientaux, et Dans la Route et de leurs Remedes, Paris : MCDDEM 1685, pp. 6-7. 
Francois Martin de Vitre wrote on the causes, treatment as well as the protection against scurvy. Those who navigate on the sea are subjected to many diseases and changes, because they breathe an impure and rough air, take coarse, spicy and gloomy meat regularly and are constrained to drink contaminated water in the absence of pure water and consume alcoholic liquid and solid food out of proportion. It is not surprising that they get affected. ${ }^{21}$

While analyzing the causes of scurvy, Dellon states that sea air and the salt provisions, both have adverse effect on blood leading to melancholy, occasioned by the tediousness and other inconveniences of long voyages. He also claims thirst, the common companion of those who are to pass into the eastern parts, and the nastiness of the mariners, who seldom keep themselves clean to be the causes of scurvy. ${ }^{22}$ This French adventurer believed that while sailing, the officers and others above the common rank were not so much subjected to scurvy as that of common sea-men, because they consumed foods which were better for digestion and nourishments. ${ }^{23}$

Martin de Vitre explains the symptoms of this disease as hypochondria, difficulty to respirate, edematous of the legs and feet, pain in kidney, tiredness all over the spine and mainly in lumbes, and when spread to the nervous system it leads to, pain in the muscles of hands and legs, paleness and sometimes yellowish colour of the face, smelling breath, the veins appearing to be strong, big and blackish, the belly, almost constipated though they made some efforts as if the stomach is half open. This is why some people called this disease scurbut. Those affected by this disease, if not diligently aided, died in fewer days the other become all swollen, having this kind of hydrops that writer named Leucophlegmatia. ${ }^{24}$

\footnotetext{
${ }^{21}$ Vitré, François Martin de, Description du premier voyage faict aux Indes Orientales par les Français, Paris: Laurens Sonnius, 1609, 2009. p. 185.

22 Dellon, Charles. Traite des Maladies aux Pays Orientaux, et Dans la Route et de leurs Remedes, Paris : MCDDEM 1685, p. 7.

${ }^{23}$ Ibid., p. 8.

24 Vitré, François Martin de. Description du premier voyage faict aux Indes Orientales par les Français, Paris: Laurens Sonnius, 1609, 2009. p. 187. 
Dellon also describes the symptoms as swelling and blackening of mouth and gums, coupled with emission of foul smell. 'This sometimes takes away a considerable quantity of corrupted flesh and matter, which not only loosens the teeth, but also often make them fall out....(also discovered by) certain black spots, which appear upon the whole body; and it is to be observed that the broader these spots are, and nearer the heart, the more dangerous is the distemper'.25 This symptom was followed by nausea, a tiredness, fainting, swooning fits, pain in the head, arms and legs, and weakness, but seldom followed by any fever that also led to smooth circulation of the blood in the vessels. ${ }^{26}$

Further, Dellon gives numerous precautions to the mariners in order to protect themselves from scurvy, firstly, 'they should take care that their ships have enough goods and provisions, that the biscuits and other provisions are not infected with fungus, (secondly) while sailing, the officers of the ship should take care to keep it neat and clean, the ship should be washed and swept with sea water every day, and is to be sprinkled two or three times a week with strong vinegar which purifies the air; (thirdly) each person on board the ship ought, as far as possible, provide himself with the juice of citrons, lemons, rossolis, preserved and dried fruits, but especially with good store of Prunes; to abstain as much as possible, from all sorts of meat... to feed much upon rice, barley and prunes, drink mixed with water...to change frequently their linens and to wash often their mouth as well as the whole body, to cleanse it from all the filth and ill scents' ${ }^{\prime}{ }^{27}$

Martin de Vitre describes some healing medicine for protection against scurvy to be carried while travelling, such as Magistral Syrup or in the form of opiates. Eating citrus fruits such as lemon or orange, or some other fruits or syrups of lemon or herbs of Cochlearia and sauerkraut were the cure. ${ }^{28} \mathrm{He}$ gave this advice to

25 Dellon, Charles. Traite des Maladies aux Pays Orientaux, et Dans la Route et de leurs Remedes, Paris : MCDDEM 1685, p. 8.

26 Ibid, p. 9.

27 Ibid, p. 11.

28 Vitré, François Martin de. Description du premier voyage faict aux Indes Orientales par les Français, Paris: Laurens Sonnius, 1609, 2009. p. 192. 
all those who were travelling on ship to take the antidotes of this disease which was very severe and dangerous.

Several other remedies to safe guard oneself from scurvy were given by Dellon. Initially use of a gentle purge and applying clysters was helpful but it was difficult to do so due to shortage of fresh water aboard these ships; secondly, washing of the mouth and rubbing of bleeding gums with mixture of some good vinegar or juice of lemons or citrons mixed with salt. If black blotches appeared on arms, legs and thighs then one must wash them often with warm sea water and bath with the blood of sea-hogs which had a quality to fight and stop the progress of this disease and lastly, he said that it could be cured by a change in weather by arriving on the shore. ${ }^{29}$ Dellon also cautioned that as soon as scurvy appeared, the patient should abstain from salty food and further suggested that sweating in cold climate backed with a good diet helps to fight this disease.

Pyrard endorses the view of others by mentioning that scurbut or le mal de terre is ordinarily brought on by the great length of the voyage and long sojourn at sea, and also by a lack of washing and cleanliness, and of a failure to change linen and other clothes; by the sea air and water, by contaminated water and the victuals, washing only with sea water without rewashing with fresh; by sleeping at night in the cold under dews. Those affected are swollen due to dropsy and the swelling thighs and legs, cheeks and throat become as hard as wood and become black being suffused with dark blood, of a livid and leaden hue, as though it were all tumours and contusions, rendering the muscles and nerves impotent and stiff. Besides this the gums are ulcerated and black, the flesh are swollen, the teeth displaced and loose, as though they had but a slight hold; indeed, most of them fall out....The discomfort is, in fact, greater than the pain, which is confined to the mouth and gums. So often a man dies while talking, drinking or eating, without knowledge of his approaching end. He reminds the

29 Dellon, Charles. Traite des Maladies aux Pays Orientaux, et Dans la Route et de leurs Remedes, Paris : MCDDEM 1685, p. 14. 
necessity of carrying orange and lemon juice before starting the voyage, in order to their protection against scurvy'30

Furthermore Mocquet gives a detailed description of his suffering from scurvy, which is called Lovende in Potugal and Scorbut in Holland. He says that the effect of the disease was such that he had fever, with a great pain in the veins, rotten gums, and a sort of black blood; his knees were so contracted that he could not bend his limbs, his legs and thighs were as black as it were affected by a type of Gangrene. He tried to get rid of the impure blood by making a cut on the affected area of his mouth with a piece of glass. But the signs reappeared next day even after the dead flesh was cut away and the black blood removed and washing the mouth with urine. He could not chew food due to pain and had to take resort to the syrup of Gilli-flowers, and good red wine. ${ }^{31}$

\subsection{Intense Heat}

Bernier suffered from intense heat stroke during the march of Aurangzeb's army from Lahore to Kashmir. He mentions that, 'I declare, without least exaggeration, that I have been reduced by the intenseness of the heat of the last extremity; scarcely believing when I rose in the morning that I should outlive the day'. ${ }^{32} \mathrm{He}$ gives detailed description of the consequences of intense heat in India. He states that, '...My Indian servants, notwithstanding their black, dry and hard skin, are incapable of further extension. The whole of my face, my feet, and my hands are flayed. My body too is entirely covered with small red blisters, which prick like needles. Yesterday, one of our poor troopers, who was without a tent, was found dead at the foot of a tree, whiter he had crept for shelter...all my hopes are in four or five limes still remaining for lemonade, and

30 Gray, Albert and Bell, H.C.P (eds.). The Voyage of François Pyrard of Laval to the East Indies, the Maldives, the Moluccas, and Brazil, Hakluyt Society, iii vols, London: Hakluyt Society, 1915. vol. II, part II, pp. 391-392.

31 Mocquet, Jean, Voyages en Afrique, Asie, Indes Orientales \& Occidentales: Divisez En Six Livres, \& enrichiz de Figures, Rouen : Jacques Caillove, 1645. p. 221.

32Bernier, Francois. Travels in the Mogul Empire AD 1656-1658 (Trans.) Irving Brock and (ed.) Archibald Constable, Delhi: Low Price Publications, 1934; 1994. p. 385. 
in a little dry curd which I am about to drink diluted with water and with sugar'. ${ }^{33} \mathrm{He}$ advises that drained dahi or curd and lemonade were considered the most refreshing in India. Bernier gives the list of necessary things to counter the heat of Hindustan. And warned of the harmful effects of alcoholic drinks which leads to burning sensation on the body specially as in hot climate few people feel a strong desire for wine, particularly of arak. ${ }^{34}$

\subsection{Guniea -Worm}

Bernier also mentions the unhealthy conditions and unhygienic products such as bread or even water available in Delhi. ${ }^{35} \mathrm{He}$ often found the bazaar bread of Delhi to be badly baked and full of sand and dust. The water had numerous impurities as it was accessible to all people and animals. This contaminated water causes 'worms to be bred in the legs which produced violent inflammation, ....They are commonly of the size and length of the treble string of a violin, and might be easily mistaken for a sinew ${ }^{\prime 36}$ called Guinea worm on account of its prevalence in Guinea... this worm inhabited the subcutaneous cellular tissue. He has shown that while extracting them great caution had to be used lest they would break; the best way was to draw them out little by little, gently winding them round a small twig of the size of a pin. Thus, Bernier gave vital information on the methods to get cured from Guineaworm. He was also critical of the meat sold in Delhi, which was roasted and dressed in different ways. It produced gas in the stomach, and was difficult to digest. The merchants even sold the meat of camels, horses and diseased dead ox, hare, pigeons, partridge and ducks besides all kinds of poultry. The meat of sheep is good though indigestible, the best meat is that of a young goat but it is best to purchase it live.

33 Ibid., p. 354. Dahi, the curdled milk was well known to all AngloIndians.

${ }^{34}$ Ibid., p. 253.

35 Bernier mentioned that the ovens in Delhi were defective, as they produced bread which was not properly baked.

36 Bernier, Francois. Travels in the Mogul Empire AD 1656-1658 (Trans.) Irving Brock and (ed.) Archibald Constable, Delhi: Low Price Publications, 1934; 1994. p.355 ft. 1. 


\subsection{Impure Water}

Tavernier mentions that the Ganga water was unclean and not safe for drinking. It is contaminated by the bathing of men and animals. He drank a glass of wine with this water which caused him great internal discomfort. But his attendants who drank it suffered much more torment. He found that the Dutch always used boiled water for drinking. He says that the Indians were accustomed to drinking Ganga water from their childhood 'even the Emperor and all his court men drink no other' than Ganga water. ${ }^{37}$ Tavernier believes that 'dieting while in India is the sovereign remedy for all kinds of ills' whereas most of the French soldiers suffered from fever due to overeating after being hungry for many days. ${ }^{38}$ This water causes fever which is difficult to cure. ${ }^{39}$

Joseph Tieffenthaler, Jesuit missionary and geographer, talks about stomach infection spread by water in the Gujarat region. He says that 'the inhabitants use rainwater, which is collected in summer in March, which breeds fishes, frogs, lizards and leeches. When these ponds are desiccated, one draws water from wells, but even this contains sea salt which causes fever and various annoying stomach infections. ${ }^{40}$ In Assam, Jean-Baptiste Chevalier's [French explorer and Governor of Chandernagor] troops complained about the poor quality of water of the river Panchonia and bad air contributed to a type of violent fever which robbed them their strength to move.41

Abbe Carre fell ill during his voyage when he drank cold water of the river. The local people 'warned me unceasingly that I was risking death or a severe illness. They themselves, though of the

37 Tavernier, Jean Baptiste. Travels in India, 1640-67, (Trans.) V Ball, iii vols. New Delhi: Oriental Books, 1889; 1977, Vol. 1, p. 95.

38 Ibid., Vol. I, p. 199.

39 Bernier, Francois. Travels in the Mogul Empire AD 1656-1658 (Trans.) Irving Brock and (ed.) Archibald Constable, Delhi: Low Price Publications, 1934; 1994. p. 271.

40 Tieffenthaler, Joseph. Description historique et géographique de l'Inde , 3 vols, (ed.) by Jean Bernoulli., Berlin, Londres: W. Faden, 1786-1789. p. 406.

41 Chevalier, Jean-Baptiste. The Aventures of the Jean-Baptiste Chevalier in Eastern India (1752-1765), trans. Jean Deloche \& Caroline Dutta-Baruah, New Delhi : LBS Publication, 2008. p. 146. 
country, never dare to drink water in strange places without first boiling it, for they understand the peril they run in drinking this bad river-water, which is most unhealthy'. ${ }^{42} \mathrm{He}$ fell ill with giddiness, which turned into a violent headache, then to sickness and a collapse that lasted for four hours and reduced him to extremity. 'His servants and Christians helped him to recover, someone advised him to try Hindu medicines while others brought certain herbs and while others put his hands behind his back then put his face downwards, the most powerful of them put his feet on his back, pulled on the silk belts, with which he was bound tightly at three points with all his strength...[H]e made all my limbs crack, and I thought he would pull them off. After having given me this treatment five or six times continuously, he filled my eyes, ears, mouth and nose with a composition of water and pounded pepper, cardamoms, and other drugs, so strong that it drew a yellow liquid from all these parts of the head' ${ }^{43}$ He thought that his brain has melted due to this intense pressure and heat. Then he says that they made a medicine of 'cow urine, horse dung, the juice of some herbs and other drugs' which he was made to drink as a remedy for the illness. ${ }^{44}$

\subsection{Disease of Bicho and Leeches}

Charles Dellon mentions another disease spread by bicho which in Portuguese means an earth-worm, or small creature of three types. The first type of worm, long and pretty thick, infects the legs, causes intense pain, and develops ulcers forming incurable gangrene at the last stage. According to the writer, one can get rid of it by pulling out the worm, winding it gradually round a large needle or small sticks, cutting open the affected area, applying common detergents to the ulcer which cicatrizes the wound. The bicho of the second kind is too small to be seen even by the most clear-sighted, which enters without causing any sensation through the pores of the skin, especially in the feet, insinuate themselves

42 Carre, Abbe. The Travels of Abbe Carre in India and the Near East, 16721674, English (Trans.) by Lady Fawcett, (ed.) Charles Fawcett and Sir Richard Burn, 3 Vols., London: Hakluyt Society, 1947, Vol. 1., p. 267.

43 Ibid., p. 268.

44 Ibid., p. 269.

30 
betwixt the flesh and the skin, and sometimes settle under the nails. Within a fortnight they breed and eventually grow up to the size of a pea, black in colour. The safest way to do away with them is, to take them out as soon as they could be sensed, for the longer they remain in the skin, the more difficult they are to be taken out; and, if they are there for long, malignant ulcers develop on the damaged skin. Another distemper also called by the name Bicho, is common inflammation, accompanied by heat-aches and burning sensation in the affected part, if neglected, it leads to malignant ulcers. ${ }^{45}$

As a remedy Dellon suggests the cleaning of the affected parts of the body, between the fundamentals, from the beginning, with a decoction made of lemon which often cures the distemper with ease. But in case the skin is already damaged, the use of some amount of gun-power, diluted in sufficient quantity of rose or plantain water ought to be applied with linen which is cleaned in the decoction of lemon'. ${ }^{46}$

Talking about the remedy to the disease of bicho which causes head and limb ache, and incurable ulcer leading to death, Pyard recommends a quarter of salt or lemon to be applied on the base three or four times, for a quick cure.

Thevenot observed the Indian remedy against the bite of serpents or venomous creatures. He says a little amount of blood is to be let out of the wound with a pick of a needle, and the stone ${ }^{47}$ is applied on the wound which must be left there till it drops off by itself. Then it must be rubbed with the milk of a female, or if none available, of cow and put on the wound. This will suck all the venom that the snake had released, but if it is of no use, it will

\footnotetext{
${ }^{45}$ Dellon, Charles. Traite des Maladies Particulieres aux pays Orientaux, et dans la Route, Paris: M.C.D.D.E.M, pp. 51-52.

${ }^{46}$ Ibid, pp. 55-56.

47Thevenot mentioned about the stones of Cobra which are composed of Ashes of burnt roots, mingled with a kind of Earth they have and once again burnt with the earth, which afterwards is made up into a Paste of these stones are formed. The stone is supposed to remove the venom by absorption when applied against the wound.
} 
burst. ${ }^{8}$ He further says that there were many venomous scorpions in India, but the Indians have several remedies to cure their sting and the best of all is fire. They take a burning coal and put it on the wound and hold it there as long and as near as they can. The poison is perceived to work out of the wound little by little and in a short time, one is perfectly cured. ${ }^{49}$

Another typical problem faced by the travellers who passed through moist forest in south India, was the danger of the attack of leeches which cling to the legs or thighs and suck the blood. As a result they became weak and feeble. Tavernier said, the leeches of this country are small and slender and live in grass and not water. As a remedy given by the Brahmins, the leaves of a certain plant is to be rubbed on the legs, the odour of which the leeches could not bear. The Brahmins also used to provide each of them with a piece of cloth containing a kind of egg-sized chalk to be used to remove the leeches clinged to their leg. If done so, the leeches would fall immediately'. ${ }^{50 I t}$ was also proved that salt and fire had the same effect on the leeches.

Another problem faced by the travellers was that of being bitten by venomous snakes. Dellon states the presence of different kinds of adders in the Indies and some of which were very poisonous and whose infection left least hope of any relief or survival. Among them, he says that the green ones, found in the coast of Malabar, whose venom did not activate fast, giving some time to obviate the evil by proper antidote. In Indies some stones, found in the head of some serpents were used to cure snake bite ${ }^{51}$ If these stones, when applied on the wound caused by the venomous creature, hold themselves tightly, without any support, they suck as much poison, as they were able to contain and fall off. These were then

48 Thevenot, Jean de. Voyage de Mr. De Thevenot, III Part ed. Surendranath Sen, Travels of Thevenot and Careri, Delhi: National Archives of India, 1949, p. 46.

49 Ibid., p. 72.

50 Tavernier, Jean Baptiste. Travels in India, 1640-67, (Trans.) V Ball, iii vols., New Delhi: Oriental Books, 1889; 1977, Vol. 1, pp. 198-200.

51 Dellon, Charles. Traite des Maladies Particulieres aux pays Orientaux, et dans la Route, Paris : M.C.D.D.E.M, p. 47. These stones were called by the Portuguese as Pedra de Cobre or Adders stones. 
put in milk. If they get back their previous look after the poison is dissolved it was an evident sign, then the poison is removed from the wound. In case one did not possess adder stones the best way to get rid of venom was to cut open the wound, draw out as much blood as one could and afterwards apply anti-venom remedies which could draw out poison, from the centre of the body to its circumference. He also states that it is better to keep the wound open for a considerable time, also to use juice of citrons or lemons in everything you eat or drink and take inwardly the true power of vipers'. 52

\subsection{Small Pox}

Charles Dellon says that one does not know about any other plague in the Indies besides the small pox, which is as contagious as there in Europe. But as the toxic matters come out through the open pores (caused by heat) of the skin, they wreck worse havoc here than in Europe. Hindu physicians were shocked to see how the Europeans tackle the bleeding and clysters before the eruption of the pustules in an organized way and though they found the process to be successful, they could not overcome their own obstinacy to follow it. The Malabares keep the patients at a good distance from their dwelling places, under some trees and treat them as untouchables till completely cured. The only care that they take for the patients was to bring some Cange for them. They do not bother to see whether they eat it or not.

Chevalier noted a disease common in Bengal called small pox against which no precautions were taken. This disease was transmitted to Tibet from Bengal along with the travellers and merchants. ${ }^{53}$ Thevenot said that many cases of small pox and Akeron were spotted in the kingdom of Gokunda. Akeron, which affected the children, was an inflammation of the tongue and mouth, due to intense heat. The parents of the patients are careful to cool them

52 Ibid., p. 48-50.

53 Chevalier, Jean-Baptise. The Adventures of the Jean-Baptiste Chevalier in Eastern India (1752-1765), trans. Jean Deloche \& Caroline Dutta-Baruah, LBS Publication, New Delhi, 2008, p. 83 
from time to time with herbs that are good against the disease, lest it seizes the guts, reaches to the fundament and kills the child. ${ }^{54}$

\subsection{Venereal Diseases}

Europeans brought along with them venereal diseases such as syphilis which was noticed as early as the sixteenth century which were called Firangi roga [disease of the Europeans]. ${ }^{55}$ According to Bernier venereal diseases were common in India, but they were 'not of so virulent a character, or attended with such injurious consequences, as in other parts of the world' ${ }^{56}$ The Indians enjoyed better health, but lacked power, vigour and energy, which affected their body and soul as compared to the French people who lived in colder climate. This was observed by the travellers. Excessive heat attack was the reason for continuous malady, which afflicted everyone indiscriminately, particularly the Europeans, who were not accustomed to such heat and had to adjust to the hot Indian summers.

François-Xavier Wendel, the French Jesuit, mentions the way a physician diagnosed women patients of seraglio which seems to be the trend since the time of Bernier. He says 'when one of these women of some distinction takes ill and cannot go to the parlour, a physician is brought, blindfolded. After reading the pulse of the patient through a veil which covers and conceals her hand, the physician is led again in the same way outside the seraglio, without his knowing where he had been... there were women who enter

\footnotetext{
54 Thevenot, Jean de. Travels of Thevenot and Careri, p. 151; Gray, The Voyage of François Pyrard of Laval to the East Indies, p. 147.

${ }_{55}$ Kumar, Deepak. 'History of medicine in South Asia, Some concerns, some questions', at Institute of History and Philology Academia, 4-8 November 2003, p. 9.

56 Bernier, Francois. Travels in the Mogul Empire AD 1656-1658 (Trans.) Irving Brock and (ed.) Archibald Constable, Delhi: Low Price Publications, 1934; 1994. p. 254.
} 
and apply remedies, phlebotomies and assume most of the functions of a physician or surgeon' ${ }^{57}$

In 1775, Antoine-Louis-Henry Polier another French adventurer sent some medicines to Raja Garhwal Lalit Shah to revive his vitality. Polier had good knowledge of medicines which helped him instruct the raja. 58

\subsection{Plague}

Bernier, while in Egypt, wrote that, 'I allude, among other conceits, to the notion that there is a certain determinate day on which the Nile begins to increase; that a particular dew, called the Goute, falls on this day of the increase, which puts an end to the plague, no person dies of that disease when the Goute has begun to descend'. 59 He saved the life of M.de Bermon, French vice-consul at Rosetta who was infected with plague by prescribing proper remedy and operating the abscess. When he himself was afflicted with the infection, he used the butter of antimony for immediate relief. He saw that men died of plague after the descent of the Goute. But he himself consumed emetic at the commencement of the disorder which helped him recover quickly. Bernier mentions, 'A Bedouin servant attended me; he endeavored to keep up my spirits by swallowing, without a moment of hesitation...I am far from denying that this distemper is generally attended with less danger after the fall of the Goute'. ${ }^{60}$ In Bernier's opinion, 'the mitigation of the disease is owing to the heat of the weather, then very intense, which opens the pores and expels the pestiferous and malignant humours that remained confined in the body'. ${ }^{61} \mathrm{He}$ was an ardent

57 Wendel, François-Xavier. Wendel's Memoirs on the Origin, Growth, and present state of Jat power in Hindustan (1768), edited \& annotated by Jean Deloche, Pondicherry: Institut Français de Pondicherry, 1991. p. 111.

58 Polier, Antoine-Louis Henri. Ijaj-i-Arsalani: Persian letters of Antoine Polier, translated into English by Muzaffar Alam \& Seema Alavi, Delhi: OUP, 2001, Folio no. 241a, p. 238-239.

59 Bernier, Francois. Travels in the Mogul Empire AD 1656-1658 (Trans.) Irving Brock and (ed.) Archibald Constable, Delhi: Low Price Publications, 1934; 1994. p. 450.

60Ibid., p. 451.

${ }^{61}$ Ibid., p. 451. 
believer of metempsychosis and was entertained with its wonderful tales.

\subsection{Cholera}

Thevenot, while returning to Surat, on the way to France fell ill from cholera and learnt the way to cure it. He states that the Portuguese believe that there were four types of cholera in the Indies Mordechin. 'The first is a bare cholera, but that causes sharp pains, the second, besides the pain causes a looseness. They are troubled with the third, accompanied by violent vomiting with the pain, and the fourth produces all the three symptoms and this last is taken to be the cholera morbus. These distempers occur most commonly from indigestion and cause sometimes such intense pain that could kill a man in four and twenty hours' ${ }^{6}{ }^{62}$

The disease of cholera also troubled the travellers during their journey to India. Dellon says, the disease that the Orientals call Mordechi, is probably nothing more, than indigestion, very frequently occurred amongst the Indians, who have weak stomachs due to high pulse beat and constant sweating. Excess drinking and eating food which are difficult to digest, taken particularly the evening, are the ordinary causes of this evil. Its main symptoms are severe head ache, anxiety, fever, delirium, looseness and vomiting, uneven pulse and, urine of the red or white colour. ${ }^{63}$

Regarding the remedies of the this disease, Dellon says that the first and the chief remedy, is to burn the feet of the affected person, by applying a red and untied iron as a pin, transversely under the heel at the most callous place, leaving it there until the patient had testified by his cries that he could feel the heat; and then removing it, striking some blows on the burnt skin, with a slipper or some such thing, to prevent the occurrence of a blister. He observed that the manner of burning with an Iron, as terrible as it appears at first sight, does not procure any considerable damage to the part of the

62 Thevenot, Jean de. Voyage de Mr. De Thevenot, III Part ed. Surendranath Sen, Travels of Thevenot and Careri, Delhi: National Archives of India, 1949, p. 147.

${ }^{63}$ Dellon, Charles. Traite des Maladies Particulieres aux pays Orientaux, et dans la Route, Paris : M.C.D.D.E.M, p. 33. 
body where it is applied as he had witnessed some of them to walk afterwards, as freely as before, nevertheless it stopped the violence of Mordechi, and oftentimes cures all its symptoms instantly. If the fever still continued, it was treated without danger with the ordinary remedies. He further states that many people will ridicule this process of treatment, but asks not to pay attention to it. He himself shared this view when he arrived at the Indies, but later gave it a try and practiced it more on himself than on others, and always with happy success, after having unnecessarily tried the cure of some affected people. ${ }^{64}$

Thevenot also echoes this remedy as stated by Dellon. The Indians heat up a peg of iron about half as big as ones finger red hot, clap it to the sole of the patients heel and hold it there till he be no longer able to endure it, so that the iron leave a mark behind it: the same must be done to the other heel with the same red hot iron, and the remedy is commonly so effective that the pain instantly ceases. If the patient was let to bleed with that burning, his life will be in an evident danger. Several people have told him that when they let blood ooze before the burning of the heel, the patient infallibly dies just as many days after he is let to bleed as he was ill before, but blood-letting is not dangerous two days after the operation: there are some who make use of Ligatures for this distemper, and bind the patients head so fast with a swathing-band, as if they had a mind to squeeze out his brains, they do the same with the back, reins, thighs and legs, when the patient finds no good of this ligature, they think him past cure. 65

Pyrard de Laval also writes that 'cholera accompanied with grievous headache and vomiting and much crying and most often they die of it'.66 This traveler also described the 'continuing fever

64 Ibid., pp. 32-36.

65 Thevenot, Jean de. Voyage de Mr. De Thevenot, III Part ed. Surendranath Sen, Travels of Thevenot and Careri, Delhi: National Archives of India, 1949, p. 151; Gray, Albert and Bell, H.C.P (eds.). The Voyage of François Pyrard of Laval to the East Indies, the Maldives, the Moluccas, and Brazil, Hakluyt Society, iii vols, London: Hakluyt Society, 1915. vol. II, part I, pp. 13-14.

${ }^{66}$ Gray, Albert and Bell, H.C.P (eds.). The Voyage of François Pyrard of Laval to the East Indies, the Maldives, the Moluccas, and Brazil, Hakluyt Society, iii vols, London: Hakluyt Society, 1915. vol. II, part I, pp. 13-14. 
which is cured promptly by bleeding which the surgeons take resort continually till slightest fever is present. As for pox, it is no mark of shame there, nor any disgrace to have had it several times: they even make a boast of it. They cure it without sweating, with China root. This malady prevails only among the Christians and they prefer it to fever or dysentery'. ${ }^{67}$

\subsection{Ulcer and Other Diseases}

Pyrard de Laval gives the description of the medical facilities that existed in Goa in 1608. He says that when he reached Goa with his two companions of whom one was suffering with serious ulcer and other from fatigue. They were admitted to the Royal Hospital from where they were discharged after three weeks of treatment. ${ }^{68}$ Modave wrote about a French surgeon ${ }^{69}$ who was treating Shuja ud Daulah, [Subedar Nawab of Oudh from October 1754 to January 1775], from the disease of genital ulcer but he was discharged and an English doctor was appointed who gave him only palliative. Finally, due to perpetually changing of doctors and remedies, he died on January 26, 1775.

Duperron experienced another malady, due to exertion which was called in Surat the derangement of the navel. It is the looseness of the umbilical vessels, whose extremities form the knot which is in the middle of the belly. If this looseness make the arteries rise above the knot, one is subjected to continual vomiting and when the derangement is below or towards the side, it is followed by frequent purging which, in a few days, bring the patient to the last extremity. ${ }^{70}$

\footnotetext{
67 Ibid., vol. II, part I, pp. 13.

${ }^{68}$ Ibid., p. 3.

69 Modave, Louis-Laurent de Féderbe, Comte de. Voyage en du Comte de Modave 1773-1776, edited by Jean Deloche, Paris: Ecole Française d'Extrême-Orient, 1971, p.156.

70 Duperron, Abrahma-Hyacinthe Anquetil, Extracts from the Narrative of Mons. Anquetil du Perron's Travels in India . (Trans.) By Kavasji Edalji Kanga, Bombay : Commercial Press, 1876, p. 29. 


\subsection{Vomiting}

The most common inconvenience to the travellers during their sea voyages was nausea and subsequent vomiting caused partly by the motion of the ship and partly by the change of air. Dellon says that he saw some people of tender constitution weakened by it to such a degree, that they were in no small danger of their life, by the great loss of spirit. Whereas others could not stir out of their beds for 3 to 4 months together' ${ }^{\prime 1}$ These remedies as suggested by him were: to take proper purgatives 2 or 3 times a little before taking a voyage especially if one is not a regular voyager. When you are at sea, you may mitigate the violence of it, by staying between the decks for the first four or five days of his voyage but never abstain from eating and drinking because vomiting with empty stomach is violent and can cause very dangerous Hemorrtagies [Hemorragies]'72 He also suggested taking good nourishment and little light wine as opposed to harmful strong liquor.

\section{Conclusion}

Pre-colonial French travellers were not just ordinary voyagers. They have thrown enormous light on the significant measures against the Oriental diseases in India. The in-depth study of large number of first hand sources of French travellers, gave a large amount of information regarding the diseases suffered by them or observed by them during their journey in India. Their comprehensive review of the Indian health system must have been helpful to the French travellers and subsequent adventurers of eighteenth century who travelled in the Orient world for their commercial, political or personal motives. These travellers have also evaluated and compared the differences in diseases between the Orient and the Occident, and concluded that climatic difference of both the countries was responsible for it. The symptoms of each oriental disease are narrated extensively by these travellers which has helped their contemporaries and successors to take necessary precautions against these ailments. Although most of these

71 Dellon, Charles. Traite des Maladies Particulieres aux pays Orientaux, et dans la Route, Paris:M.C.D.D.E.M,p. 4.

72 Ibid., p. 5. 
travellers exhibited the western belief in a kind of superiority of west over the east in medical knowledge, they did not hesitate to appreciate the creditability of Indian medical practices. 